\title{
The first complete leg of a passerine bird from the early Oligocene of Poland
}

\author{
Zbigniew M. Bochenski, Teresa Tomek, and Ewa Świdnicka \\ Acta Palaeontologica Polonica 59 (2), 2014: 281-285 doi: http://dx.doi.org/10.4202/app.2012.0021
}

The leg bones of a small passeriform bird are described from the early Oligocene (29 Mya) of Poland. The specimen is the earliest complete passerine leg with elements in articulation described so far, and increases the known diversity of the very scanty records of the oldest European passeriforms. In general proportions the leg bones resemble those of Luscinia svecica and other species that live in shrubs. Assignment to a family within the passerines is not possible because of the incompleteness of the fossil.

Zbigniew M. Bochenski [bochenski@isez.pan.krakow.pl] and Teresa Tomek [tomek@isez.pan.krakow.pl], Institute of Systematics and Evolution of Animals, Polish Academy of Sciences, Sławkowska 17, 31-016 Kraków, Poland; Ewa Świdnicka [gama@biol.uni.wroc.pl], Department of Palaeozoology, Zoological Institute, University of Wrocław, Sienkiewicza 21, 50-335 Wrocław, Poland.

This is an open-access article distributed under the terms of the Creative Commons Attribution License (for details please see creativecommons.org), which permits unrestricted use, distribution, and reproduction in any medium, provided the original author and source are credited. 